
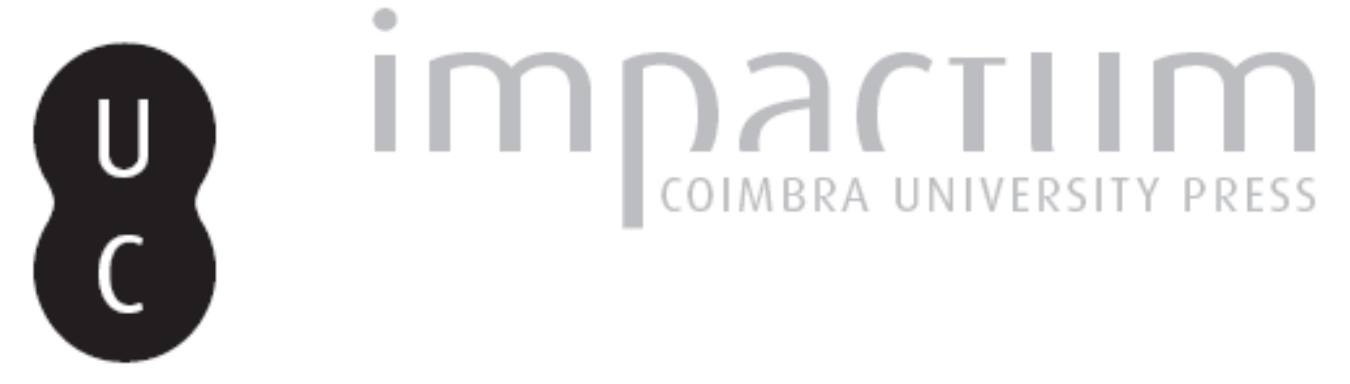

\title{
A gens Cadia em Aeminium
}

\section{Autor(es): Lucas, Maria Miguel}

Publicado por: Imprensa da Universidade de Coimbra

URL persistente:

URI:http://hdl.handle.net/10316.2/45573

DOI:

DOI:https://dx.doi.org/10.14195/1647-8657_28_9

Accessed : $\quad$ 26-Apr-2023 11:25:41

A navegação consulta e descarregamento dos títulos inseridos nas Bibliotecas Digitais UC Digitalis, UC Pombalina e UC Impactum, pressupõem a aceitação plena e sem reservas dos Termos e Condições de Uso destas Bibliotecas Digitais, disponíveis em https://digitalis.uc.pt/pt-pt/termos.

Conforme exposto nos referidos Termos e Condições de Uso, o descarregamento de títulos de acesso restrito requer uma licença válida de autorização devendo o utilizador aceder ao(s) documento(s) a partir de um endereço de IP da instituição detentora da supramencionada licença.

Ao utilizador é apenas permitido o descarregamento para uso pessoal, pelo que o emprego do(s) título(s) descarregado(s) para outro fim, designadamente comercial, carece de autorização do respetivo autor ou editor da obra.

Na medida em que todas as obras da UC Digitalis se encontram protegidas pelo Código do Direito de Autor e Direitos Conexos e demais legislação aplicável, toda a cópia, parcial ou total, deste documento, nos casos em que é legalmente admitida, deverá conter ou fazer-se acompanhar por este aviso.

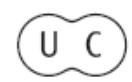


FACULDADE DE LETRAS

INSTITUTO DE ARQUEOLOGIA

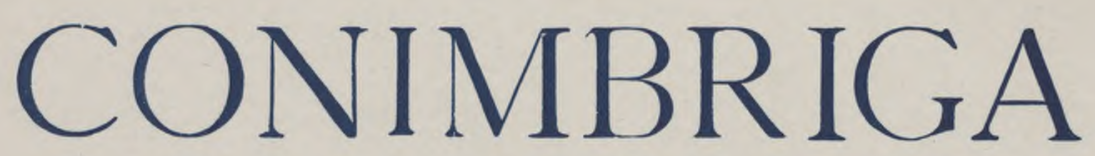

VOLUME XXVIII

UNIVERSIDADE DE COIMBRA

1989 
Maria Miguel Lucas

Licenc. em Historia, var. Arqueologia

A GENS CADI A EM AEMINIUM

Conimbriga, 28 (1989), p. 169-203

RESUmo: Numa abordagem de conjunto à epigrafia latina de Coimbra,

José d'Encarnaçâo resumia o estado actual dos conhecimentos sobre o passado romano da cidade, deixando no ar algumas pistas fornecidas por esses textos. Pegando numa delas — a frequência de menções à gens Cadia — procurámos averiguar qual a importância dessa gens na vida da civitas Aeminiensis.

Seguimos os Cádios, na medida do possível, através do Alto Império Romano, em busca das suas origens, da sua procedência, do seu estatuto social, da sua importância económica e política. Desta maneira, conseguimos recolher sete testemunhos epigráficos: quatro da Península Ibérica (sendo três do território da civitas e um do castelo de Almourol), e três de diferentes partes da Península Itálica. Do estudo que deles fizemos, pudemos reunir todo um conjunto de coincidências que nos parecem poder sugerir, entre outras coisas, o importante papel desempenhado pelas várias categorias de Cádios no seio da burguesia municipal da cidade.

Estabelecidos em Aeminium, pelo menos ao tempo de Cláudio e Nero, é nossa opinião que, de elites externas, os Cádios ter-se-ão convertido em elites internas, podendo ter contribuído, em grande medida, para o desenvolvimento económico, político e cultural local.

RESUmé: Quand José d'Encarnaçâo en est venu à traiter l'ensemble de l'epigraphie latine de Coimbra, il était en train de presenter, en s'appuyant sur les textes, l'état actuel des connaissances sur l'antiquité romaine de cette ville. Ces mêmes textes épigraphiques lui ont permis de se poser de nouvelles questions et de lancer de nouvelles hypothèses de travail. Nous avons suivi la trace de l'une de ces hipothèses: celle de la réference fréquente à la gens Cadia.

Nous avons essayé de saisir l'importance de cette famille dans la vie de la civitas de Aeminium. Dans nos possibilités, on a suivi les Cadii au cours de l'Haut Empire, à la recherche de leur origine, de leur provenance, de leur statut social, de leur importance économique et politique. De cette façon, on a récueilli sept témoins épigraphiques: quatre de la Péninsule Ibérique (trois provenant du territoire de la civitas et l'une du chateau de 


\begin{abstract}
Almourol), et trois de différents endroits de la Péninsule Italique. D'après l'étude que nous venons de faire on a réussi à réunir tout un ensemble de coincidences qui nous semblent capables de suggérer, parmis d'autres, l'important rôle joué par les différents catégories de Cadii au sein de la bourgeoisie municipale de la ville.

Établis à Aeminium, du moins au temps de Claudius et Nerus, les Cadii, d'abord des élites à l'extérieur, sont devenus des élites à l'intérieur et peut-être ils ont pu contribuer au dévellopement politique, économique et culturel local.
\end{abstract}




\section{A GENS CADIA EM AEMINIUM}

Muito ficou por saber acerca do passado histórico da cidade de Coimbra. A existência de um povoado pré-romano local adivinha-se na subsistência de tradições indígenas $i^{1}$ ), patentes nos diferentes documentos da romanização que até nós chegaram, embora tal não esteja comprovado. Somos levados, pelas fontes clássicas, a identificar como célticas essas tradições, o que foi, aliás, confirmado pelos estudos linguísticos e filológicos efectuados $\left({ }^{2}\right)$.

Foram ainda essas fontes que nos deram a conhecer a existência de uma Aeminium, cidade estipendiária da Lusitânia ( ${ }^{3}$ ), náo adiantando grande coisa quanto à sua localização. Terá, talvez durante o século i $\left({ }^{4}\right)$, ascendido à categoria de municipium, sendo já sede de civitas.

As ruínas de Aeminium jazem sepultadas sob a actual cidade de Coimbra e, mais profundamente ainda, sob os vários metros de aluviáo do Mondego. Testemunhos dispersos do seu passado romano puderam ser claramente interpretados à luz da epigrafia, a qual também aqui se distinguiu como fonte privilegiada, possibilitando o estabelecer de um fio condutor no conhecimento histórico : o forum pôde ser identificado por uma inscrição consagrada ao Génio da Basílica $\left(^{5}\right)$; a cidade, que até 1888 tinha sido confundida com Conimbriga, pôde ser indubitavelmente identificada com

(!) EncarnaÇão, 1979, p. 172-173; Alarcão, 1988, vol. II, p. 95 $(3 / 106)$.

(2) Le Roux e Fabre, 1971, p. 130; Alarcão, ibidem.

$\left({ }^{3}\right)$ EnCarnaÇão, idem, p. 173, cit. Plínio, H. N., IV, 118.

(4) Le Roux e Fabre, 1971, p. 121; EnCarnaÇã O, idem, p. 175.

(5) LE Roux e FABRE, 1971, p. 119-21. 
Aeminium graças à descoberta de uma inscrição dedicada a Constâncio Cloro pela civitas Aeminiensis (6); as quinze inscrições até hoje encontradas no território da civitas puderam trazer alguma luz sobre o que diz respeito ao nível cultural da sua população, à sua indubitável raiz étnica pré-romana, às suas relações com outras civitates (nomeadamente Emerita Augusta), à sua economia, ao seu estatuto legal $\left({ }^{7}\right)$.

José d'Encarnaçâo ${ }^{8}$ ), baseando-se precisamente nestas fontes epigráficas, abordou já o problema da constituição da sociedade eminiense, inferindo a existência de uma onomástica de raiz latina - tanto a nível de nomen como do cognomen associado - a par de uma onomástica de raiz indígena, estando a fusão destes dois ramos populacionais também documentada, índice claro de uma rápida romanização. Pôde ser salientada por este autor a frequência de determinadas gentes latinas como os Iunii, Iulii e Aurelii, e ainda de outras que, embora não tão comuns, não deixam de ser, por isso, menos significativas - por não provirem de uma raiz latina, por aparecerem documentadas em inscrições com afinidades estéticas com as de Conímbriga, afinidades essas que provêm, sem dúvida, do mesmo substrato indo-europeu de que ambas as cidades partilham.

Um dos gentilicios referidos neste âmbito pelo autor é precisamente o dos Cadii, aquele que ora nos propomos estudar, numa tentativa de esclarecer um pouco o motivo pelo qual uma gens tão pouco frequente aparece documentada em três das apenas quinze inscrições provenientes de Coimbra, qual a sua razão de ser na Hispania (mais concretamente na Aeminium da Lusitânia romana), qual a sua origem, a sua importância social, qual o seu possível contributo no desenvolvimento da civitas eminiense.

Começamos assim por apresentar, num pequeno catálogo, os testemunhos de Cadii recolhidos, todos já publicados por Hübner e/ou por outros autores que oportunamente indicaremos, tendo sido por nós efectuadas algumas revisões de leitura nos casos em que observámos serem necessárias.

(6) Alarcão, 1983, p. 65 e 95-6.

(7) EnCarnaÇão, 1979, p. 172-78; Le Roux e Fabre, 1971, p. 124-25.

(8) ENCARNAÇão, ibidem, p. 176-78. 
Sâo sete inscrições ao todo: quatro da Península Ibérica, (sendo três do território da civitas e uma de Almourol) e três de diferentes partes da Península Itálica. Quanto às exógenas à Hispânia, apenas apresentamos as inscrições referidas nos corpora a que tivemos acesso, ou noutro tipo de obras que lhes fizeram uma referência indirecta, pelo que não nos terá sido possível, talvez, abarcar todos os testemunhos conhecidos no mundo romano.

Todos os documentos da Hispania se encontraram em reutilização, dois dos de Coimbra incorporados nas muralhas.

\section{O catálogo epigràfico da Gens Cadia}

CIL II $380=$ ILER 4872.

$[\ldots] / \mathrm{G}$ (aio). K[A]DIO . [...]NILANI / ANN (orum). XXXVI \{triginta et sex) / G \{aius). K[A]DIVS SALVIANVS / F (ilio). ET . ALBANIA / ANCHIALE . MARITO / F(aciendum) . C(uraverunt). $\mathrm{S}($ it $)$. T(ibi) . T(erra) . L(evis) .

Bibliografia:

CIL II 380; ILER 4872.

(...) A Gaio Càdio (...) nilano, de 36 anos. Mandaram fazer Gaio Cádio Salviano ao filho e Albânia Anchiale ao marido. Que a terra te seja leve.

Trata-se de um documento encontrado em reutilização numa parede de Coimbra. De mármore, não conhecemos a sua tipologia. O texto perdeu-se, pelo que não é possível apresentar senão a leitura de Hübner e Vives. $O$ espanhol não terá copiado atentamente o texto do primeiro, uma vez que não indica todos os puncti distinguentes, razão por que adoptámos aqui a leitura do CIL II. A paginação está correcta, como o latim utilizado. A pontuação foi bem empregue. Talvez se possa falar de alinhamento à esquerda, ou de uma preocupação de centrar o texto no campo epigráfico, dado 
o número irregular de caracteres empregues em cada linha (cf. 1.2 e 3). De notar o emprego do nexo AL na linha 3, devido, sem dúvida, a uma sobrecarga de caracteres no espaço. As abreviaturas e siglas foram correctamente utilizadas, possivelmente com a mesma intenção, uma vez que não sabemos a forma como foram distribuídos os caracteres em cada linha, nem as dimensões do campo epigráfico.

De notar a ausência da consagração aos Manes, talvez devida ao estado fragmentário do monumento ou à sua difícil inteligibilidade. É difícil adivinhar o cognomen desaparecido, embora se trate certamente de uma palavra da3. ${ }^{\text {a }}$ declinação no dativo singular $\left({ }^{9}\right) \ldots$ A terminação -ani não será muito vulgar numa palavra da $3 .^{\mathrm{a}}$ declinação, característicamente de tema em -o. Desta forma, e porque integrada num contexto antroponimico classificável como «orientalizante», pusemos a hipótese de se tratar de uma transcrição latina literal do grego. Descobrimos, assim, que em grego, efectivamente, certos adjectivos triformes, quando declinados no dativo singular da sua forma masculina (e neutra), terminam em avi $\left(-a / z_{i}\right)$, se se tratar de palavras de tema em a $\left({ }^{10} 11\right)$.

Quanto ao cognome Salvianus, é incluído por Kajanto num grupo que parece ter derivado de praenomina raros e obsoletos $(u)$.

Os Cádios apresentam-se aqui ligados à gcres latina dos Albanii que, na Hispánia, parece estar documentada apenas em Cádis( $\left.{ }^{12}\right)$. Os Albanii (13) parecem ter sido uma das famílias mais antigas e importantes do Lácio: um Caio Albânio é mencionado em Cícero (Att. XIII, 31.4) a propósito de uma compra de propriedades. À viúva foi dado um cognome, Anchiale, de que não encontrámos outro testemunho. O seu paralelo latino poderá ser Anchialus, nome de uma cidade grega da Tràcia, que foi, porém, usado para

$\left.{ }^{9}\right)$ De acordo com M. L. Albertos (1976, p. 62-3), poderia tratar-se de um patronímico, no genitivo ou sob a forma de cognomen; contudo, não parece provável que se quisesse aqui reforçar a menção da filiação uma vez que ela aparece expressa, indirectamente, mais adiante.

(10 11) Por exemplo, [xeAaa, avo $<$ r, faz p,sAavi no dativo singular (GoodwIN, 1983, p. 86).

(11) KAJAnto, 1965, p. 177.

(12) ILER 2824,2901 e 5726.

(ia) SCHUlze, 1966, p. 532-3; R. E., I 1, p. 1305. 
identificar escravos: Cícero, por exemplo, alude a um Anchialus servus (Fam. XIII, 45) $\left({ }^{14}\right)$. Tal circunstância levar-nos-ia a integrá-lo no grupo classificado por Kajanto como cognomina geográficos ou relativos à origem (1S). No entanto, em grego ' $A y^{\wedge} \operatorname{taX}^{*} /$ ) é o nome de uma ninfa do mar, não tendo equivalência em latim $\left({ }^{16}\right)$. Esta ausência de equivalente denota, desde já, um bom conhecimento da língua grega por parte de quem pôs o nome à escrava. Tudo isso nos leva a pensar que estamos em presença de uma liberta, e, mesmo, de uma família de libertos: todos os Albanii documentados em Cádis apresentam cognomes com aparente filiação grega - Martilla, Artemidorus, Quintilius - e um deles apresenta-se expressamente como liberto.

Quanto à cronologia do monumento, em virtude da fórmula final S.T.T.L., da indicação da idade, da expressão lacónica dos laços familiares e, quiçá, da ausência da fórmula inicial de consagração, atribuí-la-íamos à segunda metade do séc. i d.C., finais quando muito, devido ao emprego de S.T.T.L.

O padrão irrepreensível do formulário, a utilização do dativo na identificação do falecido e o emprego dos nexos apontam, sobretudo se os associarmos à sua cronologia alta, para um elevado grau de cultura, tanto dos dedicantes como do lapicida, para além de se tratar de um monumento de mármore, indiciando simultaneamente um determinado nível económico. Por tudo isto, não pensamos que se trate de indígenas. A ligação matrimonial de dqas gentes de origem servil, mas exógena, parece estar aqui, portanto, documentada.

CIL II $5241=$ ILER 3793

$\mathrm{D}$ (iis) (hedera) $\mathrm{M}$ (anibus) (hedera) S [aerum) / CADIO / / CARIANO / ANN(orwm) (hedera) XXI (viginti unius) I

(14) R. E., 13, p. 2105.

(15) KaJANTO, 1965, p. 80-2.

(16) BAILlY, 1941, p. 18; BÉSNIER, 1914, p. 47. 
ALLEIGEA / AVITA MATER / FILIO FAC(iendum) . C(uravit) . / DIC . ROGO QUI . TRANSIS SIT . TIBI . / TERRA LEVIS $\left({ }^{17}\right)$

Bibliografia:

Borges de Figueiredo, 1888, p. 126; Filipe Simões, 1888, p. 19; Virgíllo Correia, 1946, p. 20; CIL II 5241 ; M. L. Rodrigues, 1959-60, p. 121 ; ILER 3793; ANGELA RESENDE, 1971, p. 671-73.

Consagrado aos deuses Manes. A Cádio Cariano, de 21 anos. A mãe, Aleiceia Avita, cuidou que fosse feito ao filho. Ó transeunte, rogo-te que digas: «Que a terra te seja leve!».

Monumento de calcário, medindo 1,04 X 0,46 X 0,34, encontrado também em reutilização na muralha de Coimbra. Hübner e M. L. Rodrigues classificam-no como «cipo», mas talvez os dois orifícios que observamos na parte superior possam indiciar a sua função de pedestal. Actualmente, no Museu Machado de Castro (n. ${ }^{\circ}$ de inventário antigo: $7 ; \mathrm{n}^{\circ}{ }^{\circ}$ de inventário de secção: E-149 EP-3).

O campo epigráfico foi duplamente moldurado; as faces laterais apresentam diferentes instrumentos scriptoria em alto-relevo. O texto está perfeitamente centrado, inclusive as duas últimas linhas gravadas um pouco mais abaixo na mesma capital quadrada, elegante. Pela análise paleogràfica e pelo contexto, não concordamos com M. L. Rodrigues que sugere (p. 121) terem sido estas posteriormente gravadas: a gravação em destaque teria, talvez, a intenção de melhor atrair à leitura os que passavam... As hederae são, na verdade, folhas de hera estilizadas obtidas pela sobreposição de dois pequenos triângulos; os outros puncti são também triangulares.

De salientar a omissão do praenomen na identificação do falecido. O cognomen, Carianus, parece ser aqui, de resto, o elemento de identificação: documenta-se apenas esta vez na Península Ibérica, registando-se, segundo Kajanto, um testemunho no CIL III (Ásia), um no CIL VI (Roma), e dois no CIL XII (Gália Narbonense). Aquele investigador afirma a possibilidade de serem

(17) Apresentamos a leitura por nós efectuada. 
os cognomes terminados em -ianus derivados dos cognomina de família a partir desse sufixo, vulgar $\left({ }^{18}\right)$.

E, se Gádio Cariano se pode incluir no número dos cidadãos romanos, a sua mãe, Alleicea Avita, é, verosimilmente, uma indígena: não encontrámos qualquer outra Aleicea documentada; o radical -ei patenteia ainda, segundo M. L. Rodrigues (p. 113), a sobrevivência da vocalização céltica, e M. L. Albertos relaciona o antropònimo com as formas nominais pré-romanas Alicia, Allicia, correspondentes femininas de Allucius, que considera características da área lusitana $\left({ }^{19}\right)$. Por outro lado, o mapa de distribuição da ocorrência deste nome na Península Ibérica apresentado por Untermann circunscreve-o, mais concretamente, à área da antiga Celtibéria $\left({ }^{20}\right)$. Da mesma forma, Kajanto observa que o cognomen Avitus (segundo Schulze de origem itálica, mesmo etnisca( $\left.{ }^{21}\right)$ ) étão abundante na Hispania e noutros países célticos que essa popularidade só pode ser atribuída à existência de um substracto étnico nacional, por haver, casualmente, palavras célticas e latinas homófonas (22). Seria, normalmente, utilizado para designar pessoas de alto nível social, o que é mais um argumento a favor da tese da importância dos Aviti e do seu papel, aqui, de elites locais (23).

Pela tipologia do monumento, pelo cuidado extremo que parece ter sido posto na sua elaboração (altos relevos laterais, centralidade do texto, pontuação e seu emprego), poderemos, ainda aqui, associar um elevado nível cultural a um bom poder económico, o que a decoração lateral com instrumentos de escrita parece comprovar «num elogio à cultura, à instrução» $\left({ }^{24}\right)$.

A ausência de filiação dever-se-á, possivelmente, ao facto de Cádio Cariano ser um filho natural, fruto da ligação ilegítima de um Cádio com uma indígena. Contudo, a consagração inicial abreviada, a ausência de praenomen, a indicação da idade e o

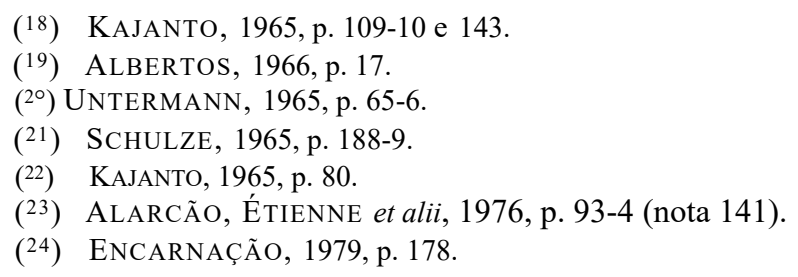


emprego da fórmula final (neste caso, também personalizada) podem datar o monumento dos fins do séc. $\mathrm{n}$, inícios do séc. $\mathrm{m}$ d.C., apesar da não utilização de adjectivos de superlativação na expressão das relações familiares. Esta cronologia seria também susceptível de explicar a não indicação da tribo. Paleograficamente ("), porém, insere-se indubitavelmente nos tempos de Cláudio e Nero, o que recua a sua datação para os meados do séc. i..., atestando o nível cultural de quem escreveu o epitáfio.

\section{ILER 4082}

$\mathrm{D}$ (iis) (hederá) M (anibus) S (aerum) [ L (ucio) (hederá) CADIO CELLAE . ANN(orwm) / XXVII (viginti et septem) . L(ucius) . CADIVS . CARVS . / ET . VALERIA . RVFINA . / PARENTES . $\mathrm{F}$ (ilio) . OPTIMO . / F (aciendum) (hederá) C (uraverunt)

Bibliografìa :

VASCONCELOS, 1913, p. 101-2; M. L. RodRIGUes, 1959-60, p. 118-9; ILER 4082; ANGELA RESENDE, 1971, p. 673-4 (26).

Consagrado aos deuses Manes. A Lúcio Cádio Cela, de 27 anos. Os pais, Lúcio Cádio Caro e Valéria Rufina, mandaram fazer ao filho óptimo.

Placa de calcário, de $0,90 \times 1,45 \times 0,28$, proveniente de Montemor-o-Velho. A moldura, dupla, é profusamente decorada. Os elementos decorativos seguem os padrões clássicos vegetalistas, folhas de acanto e volutas, parecendo ter sido retirados de um capitel da ordem mista. O calcário apresenta-se muito corroído pela acção da humidade, a que as condições em que se encontra no museu de Coimbra $\left(n .^{\circ}\right.$ de inventário antigo: $149 ; \mathrm{n}^{\circ}$ de inventário de

(26) Cagnat, 1914, p. 4-5.

(26) O erro de leitura cometido por Leite de Vasconcelos foi corrigido pelos autores posteriores. 
secção : E-152, EP-6) — num local húmido do criptopòrtico — o expõem constantemente... Todo o texto se encontra em monumental quadrada, tendo sido cada letra rigorosamente inscrita no espaço que lhe competia. O mesmo cuidado foi posto na centralização do texto no campo epigráfico, com evidentes preocupações estéticas. As hederae são, ao contrário das do monumento anterior, perfeitamente realistas e bem desenhadas. Ressalta da pedra toda uma monumentalidade que nos leva a supor ter estado implantada numa estrutura funerária de iguais características. Ainda desta vez, a boa cultura latina dos Cádios se alia a um forte poder económico, bem patente...

Montemor-o-Velho situa-se a poucos quilómetros de Coimbra e na mesma margem do Mondego. Este rio devia funcionar como fronteira natural divisória do território das civitates de Conímbriga e Aeminium, pelo que Montemor pertenceria ainda ao território da civitas Aeminiensis. A inscrição não se encontrou in situ, porém, analisando a carta de distribuição dos vestígios romanos da área, encontramos na Senhora do Desterro uma referência de Santos Rocha ao achado de alicerces, mosaicos, diversas moedas romanas e sepulturas. Tratar-se-ia, decerto, de uma villa romana com a sua necrópole. Porque não identificá-la como sendo a villa dos $L$. Cadii, tendo pertencido esta placa monumental ao jazigo de família? É, em nossa opinião, uma hipótese a considerar. Perto, no Ferrestelo, o mesmo autor localiza ainda uma necrópole de inumação, sendo, no entanto, na opinião de J. de Alarcão, duvidosa a sua cronologia romana $(27)$.

Temos, assim, documentados laços familiares entre duas gentes aparentemente latinas : os Cadii ligam-se matrimonialmente aos Valerii, uma das primitivas gentes maiores da Península Itálica ${ }^{28}$ ). O cognome Rufinus não indicia nunca uma origem servil, não abundando mesmo, segundo Kajanto, entre os libertos. Será mais um derivado, por intermédio do sufixo -inus, do cognome Rufus, este característico de ingenui e, nomeadamente, da classe senatorial masculina, pelo que só com relutância era atribuído a escravos.

(27) Alarcão, 1988, p. 96-7 (3/127: Rocha, 1903, p. 596-8; Cruz, 1898, p. 277) e p. 96 (3/124: RоснA, 1971, p. 92-5).

(28) R. E.,VIIA2,p. 2292-6. 
É também muito raro em mulheres $\left({ }^{29}\right)$, mesmo em «patrícias». Segundo as regras de transmissão de nomes, esta Valéria teria recebido o cognome de seu pai ou seu avô Valério. Não pensamos, de qualquer maneira, que se trate de uma indígena.

Pertenceria, porventura, à importante família dos Valerii de Conímbriga $\left({ }^{30}\right)$ ?

Os cognomina Cella e Carus são característicamente latinos. Quanto ao primeiro, parece provir de uma qualquer característica profissional ${ }^{31}$ ) ... Kajanto não cita qualquer outro exemplo, mas sabemos que em tempos uns L. Cellae terão lutado contra César ( $\left.{ }^{32}\right)$. O segundo é também característico de homens livres, embora não seja dos mais frequentes; insere-se no grupo de cognomes relativos a determinadas circunstâncias ( ${ }^{33}$ ), indicando, designadamente, o que os outros pensam ou sentem pela pessoa.

Para avançar uma datação deste monumento, podemos socorrer-nos da presença da invocação abreviada, da indicação da idade, dos laços de parentesco superlativos, o que parece remeter para os finais do séc. $\mathrm{n}$ ou talvez meados, em virtude da ausência da fórmula final S.T.T.L. Mais uma vez, no entanto, a análise paleogràfica ${ }^{(34)}$ o recua para os meados do séc. i, concretamente nos tempos dos dois últimos júlio-claudianos. Pelo estudo comparativo dos ducti, diríamos até ter sido gravado pelo mesmo ordinator o nosso monumento $n .^{\circ} 2$, sendo, portanto, contemporâneos.

CIL II $6271=$ ILER 3439

D\{iis) (hedera) M \{anibus) (hedera) S \{aerum) / Q (uinti) . CADI(i). FRONTONIS / ANN(orum). XXV (viginti et quinque). ROMAE .

(29) KaJanto, 1965, p. 27-8 e 229.

(30) Alarcão, Etienne et alii, 1976, p. 93-8

(31) KaJanto, 1965, p. 323.

(32) R. E., III2, p. 1871.

(33) KaJanto, ibidem, p. 284.

(34) GagNat, 1914, p. 4-5. 
DE . / FVNCTI . RELIQVIAE . H(íc) . S(ùae). S(unt) / 5 CADIA . TVSCA . AN (norum). XXX (triginta). H (ic). S (ita). E (st) / $\mathrm{M}$ \{arcus) . CADIVS . RVFVS . LIBERIS / OPTVMIS . PIISSIMIS . POSVTT / CORNELIA . FRONTONIS . F [ilia) . / AN (norum) XXIII (rigiriti et tres). ALBVRA. MATER /10 FRONTONIS. ET . TVSCAE . H (ic) . S (ita) . E (st) / CADIVS . RVFVS . VXORI . I / OPTVMAE . Y(obis). T \{erra). L(evis).

Bibliografîa:

Borges DE FigueIREDO, 1889, p. 155-6; GIL II 6271; ILER 3439; Angela Resende, 1971, p. 675-7.

Consagrado aos deuses Manes. Aqui repousam as relíquias de Quinto Cádio Frontão, de 25 anos, falecido em Roma. Aqui jaz Cádia Tusca, de 30 anos. Marco Cádio Rufo colocou aos filhos óptimos e piíssimos. Aqui jaz Cornélia Albura, de 23 anos, filha de Frontão, mãe de Frontão e de Tusca. Cádio Rufo, à mulher óptima. Que a terra vos seja leve.

Trata-se de uma placa de mármore (?), em capital actuária, de $0,56 \mathrm{X} 0,40$. Borges de Figueiredo transcreveu-a a partir de um decalque. Os autores que depois a mencionam, limitam-se a concordar com a sua interpretação, divergindo, por vezes, na cópia da sua leitura. O local em que o monumento se encontra em reutilização (como pedra de arco no castelo de Almourol - Vila Nova da Barquinha, Praia do Ribatejo) não facilita uma observação in situ pelo que também nós não o pudemos fazer. Assim, apresentamos a leitura por nós efectuada a partir de uma fotografia gentilmente cedida pelo Dr. João Manuel Bairrão Oleiro. Não concordamos inteiramente com a leitura apresentada por Borges de Figueiredo (p. 156), nem com o seu desdobramento do texto ( $\left.{ }^{3 S}\right)$.

(35) «D(iis) M(anibus) S(acrum). Q. Cadi(i) Frontonis, ann(orum) $X X V$, Jiomae defunti, reliquiae h(ic) s(itae) s(unt); Cadia Tusca, an(norum) $X X X, h$ (ic) s(ita) e(st); M. Cadius Rufus liberis optumis piissimis posuit. (...) Cornelia Frontonis f(ilia) ann(orum) XXIII (se. h. s. e.); Albura mater Frontonis et 
Não se sabe ao certo de onde veio, porém, utilizando mais uma vez a carta de distribuição dos vestígios romanos em Portugal descobrimos referências à estação de Arrepiado (Pinheiro Grande, Chamusca), na qual se encontraram alicerces, mosaicos e vestígios de cerâmica de construção $\left({ }^{*}{ }^{36}\right)$. Não será mais uma villa dos Cádios sendo a placa proveniente do grande jazigo da família? ... O facto de a placa se encontrar incorporada num jazigo de família explicaria a aparente desconexão das idades entre a mãe e os filhos, bem como a grande quantidade de espaço deixado livre logo abaixo da última linha do texto (praticamente metade da pedra), o qual se destinaria, nesse caso, a ser preenchido com os próximos elementos da família aí inumados.

O texto, alinhado à esquerda e à direita, contém a invocação inicial devidamente centrada na primeira linha. De salientar o destaque dado pelo lapicida às letras: «F» nos cognomes das linhas 6, 8 e 10; «I» no superlativo da linha 7; decerto para melhor aproveitar o espaço, uma vez que, tanto quanto nos foi possível observar, o campo epigráfico não pode ser sequer delimitado. Notar ainda o emprego dos nexos (1. 7 e 8), de maneira a aproveitar todo o espaço, indiciando um perfeito domínio do latim e das técnicas epigráficas. Notar também a elegância das duas pequenas hederae na consagração aos Manes.

$\mathrm{O}$ texto encontra-se claramente dividido em duas partes : uma dedicada por Marco Gádio Rufo aos filhos, e outra à esposa. Será esta segunda parte um acrescentamento posterior, como quer Borges de Figueiredo ? Parece-nos que não, dado que há no texto uma coesão muito grande, uma sucessão de palavras em encavalgamento que termina abruptamente, sem destaque, na fórmula final (S).V.T.L. Assim, todo o texto teria sido mandado gravar na mesma altura por alguém que, por um lado, lamenta a perda dos filhos e, por outro, chora sentidamente a morte da esposa, desgosto que o epitáfio ditado ao ordinator põe em destaque.

Tuscae h(ic) s(ita) e(st). Cadius Rufus uxori optumae. V(obis) t(erra) $l^{\wedge}$ vis)»,, concluindo a existência de uma neta Gornélia, para além da esposa de Gádio Rufo, Albura.

(36) Alarcão, 1988, p. 114 (5/60 : SAA, 1956, p. 171 e 240-1; CHAVES, 1936, p. 57). 
É possível traçar, desta forma, o stemma desta família:

FRONTO

CORNELIA ALBVRA oo MARCVS CADIVS RUFUS

QVINTVS CADIVS FRONTO

CADIA TVSCA

Mais uma vez se documenta a ligação de um Cádio com uma indígena pois, apesar da raiz latina do gentilicio, o cognome Albura assim o justifica. M. L. Albertos localiza Alburusja um pouco por toda a Península, mas sobretudo no Norte e Centro de Portugal, com prolongamentos em território espanhol (Galiza e Extremadura) $\left.{ }^{(37}\right)$. Untermann, por seu turno, diz ser este o único nome indígena, entre as formas Albicus e Albonius, que aparece a norte do Douro fora do território da Lusitânia $\left.{ }^{38}\right)$.

Kajanto explica o cognome Fronto (do avô e do neto) como mais um exemplo de homofonia entre um adjectivo latino e um indígena, eventualmente e por simples coincidência, de conotação semelhante. O sufixo -o/onis, possivelmente de origem céltica, parece, de facto, ter servido muitas vezes de pretexto para os povos célticos poderem juntar ao nome (como cognome latino) algo familiar ao seu primitivo substracto linguístico. Poder-se-ia assim explicar a quase exclusividade da sua associação a nomes masculinos $\left({ }^{39}\right)$, tendo em conta que os varões começaram a identificar-se mais cedo à latina $\left({ }^{40}\right)$.

O cognomen Tusca parece ter sido atribuído de acordo com a «moda» hispânica: dos quarenta e quatro Tuscus ; a conhecidos por

(3?) Albertos, 1976, p. 71.

(38) Untermann, 1965, p. 49-50.

("») Kajanto, 1965, p. 26,118 e 236.

(40) Albertos, 1976, p. 65-6. 
Rajanto, vinte e três são da Península Ibérica. Este autor atribui-lhe um significado de âmbito geográfico : derivaria do latim tuscus (aqueles que são provenientes da Etrúria e da Ümbria) ${ }^{41}$ ). Os Cádios, como veremos, seriam daí oriundos... A enorme frequência com que é utilizado fora da Península Itálica, encontraria, pois, justificação na intenção de perpetuar a ideia de uma origo... Não será por acaso que, no mapa apresentado por Untermann, todos os Tuscus/a se localizam no Sul da Hispânia, ao longo dos $\operatorname{rios}\left({ }^{42}\right) \ldots$

A associação de dois novos praenomina aos Cadii - Quintus e Marcus - não parece ser relevante, uma vez que é o cognomen a funcionar aqui como elemento de identificação.

Borges de Figueiredo, pela análise paleogràfica (p. 156), aponta para uma cronologia dos fins do séc. i, a que podíamos acrescentar a subsistência de uma raiz onomástica indígena, a indicação das idades e, até, a utilização da fórmula final S.T.T.L. Por outro lado, quer a presença da invocação aos Manes, quer asuperlativação dos laços familiares, podem levar, pelo menos, até aos meados do séc. II. Mais uma vez, no entanto, a análise paleogràfica nos leva aos meados do séc. i, sendo os $\langle\mathrm{P} »$ abertos empregues neste epitáfio semelhantes aos utilizados na inscrição anterior, os «R» parecidos com os da nossa inscrição $n .^{\circ} 3$, correspondendo, assim, ao período júlio-claudiano de Cláudio-Nero.

CIL X 1158

C\{́aio). RADIO . C(aii) . L(iberto) . CIMBRO / C(aio) . RADIO C\{aii) . F (ilio) GAL (eria tribu). RVFO / M (arcus). RADIVS . C(aii) . F (ilius) . GAL (eria tribu) . CELER / PAT(r)I . FRAT(r)I . SIBIQVE /VIVOS. FECIT.

Bibliografia :

PIR II, p. 1-2; GIL X 1158 ; FORCELLINI V, p. 297.

(41) KaJanto, ibidem, p. 51 e 118.

Í42) UNTERMANN, 1965, p. 179-80. 
A Caio Kádio Cimbro, liberto de Caio. A Caio Kádio Rufo, filho de Caio, da tribo Galéria. Marco Kádio Célere, da tribo Galéria, fez, em vida, para o pai, para o irmão e para si.

Proveniente de Abellinum, o texto é deveras interessante. Trata-se de um filho de liberto que, dedicando um epitáfio a seus pai e irmão, parece não demonstrar qualquer pejo em denunciar a sua origem servil. Talvez o facto se possa mesmo interpretar inversamente: neste caso, os dois cidadãos Kadii orgulhavam-se de seu pai — um poderoso liberto de K/Cádio!...

Deschamps localiza Abellinum no antigo Samnium, território próximo da actual cidade de Avellino. No entanto, Bésnier parece discordar, situando-a antes na Campania, embora junto à fronteira com o território samnita $\left({ }^{43}\right)$. Ainda segundo o mesmo autor, Abellinum terá surgido com o estatuto de colónia nos inícios do Império, o que parece concordar com as conotações cronológicas da tribo referida - a Galéria, tipicamente júlio-claudiana... Teria sido deste modo, então, que Marco e Caio Kádio ascenderam à cidadania, através do privilégio concedido pelo estatuto colonial ?... De uma forma ou de outra, podemos afirmar, mais uma vez, a importância político-económica dos Cádios, pelo menos a nível local, porque, mesmo numa colónia, só pertencendo ao senado ou desempenhando uma magistratura municipal é que se ascendia à cidadania ... o que não era extensivo a todos os cidadãos $\left({ }^{44}\right)$.

$\mathrm{O}$ antropònimo Cimber deve estar relacionado com os Cimbri, povo do Norte da Germania, de raça céltica ou germânica, que, nos últimos anos do séc. i a. C., invadiu a Gália, a Hispânia e a Península Itálica, de onde foi expulso por Mário ( ${ }^{4 S}$ ). É possível que este liberto fosse um dos escravos feitos durante estas campanhas ou o descendente de um deles... Holder refere a existência de um Cimber gallus civis e há outro paralelo ainda, registado junto ao Castro de Alvarelhos (Carriça, Maia, Porto), de um S(extus) Arqui(ws) Cim(èri) 1 (ibertus): ILER $5898=$ CIL II $2373(46)$.

(43) DESCHAMPS, 1965, p. 34; BÉSnIER, 1914, p. 2, respectivamente.

(44) Centeno, 1981, p. 169.

(45) BÉSNIER, 1914, p. 123.

(46) ENCARNAÇÃO, 1975, p. 270-4. 
Do cognomen Rufus já falámos no texto anterior (n. ${ }^{\circ}$ ). Talvez fosse Caio Cádio Rufo o filho primogénito e o cognome Rufo lhe tivesse sido atribuído em homenagem ao antigo patrono de Cimbro... Note-se, além disso, a semelhança antroponimica: na Lusitânia, Marco Cádio Rufo, casado com uma indígena; aqui, um Marco Cádio Rufo (também!...) e um Caio Cádio Rufo, filhos de Caio Cimbro; a norte do Douro, Sexto Árquio, liberto de um Cimbro...; irá aparecer-nos, ainda, um Caio Cádio Rufo, procônsul da província asiática do Ponto e da Bitínia (p. 20)...

Quanto ao cognome de Marco Cádio, Celer, Kajanto engloba-o num sub-grupo de nomes relativos a características físicas e mentais: os que sugerem rapidez ou lentidão, qualidades estas referentes quer à agilidade física, quer à mental $\left({ }^{47}\right)$. Parece ter sido um cognomen de atribuição quase exclusivamente masculina e de ingenui, muito raramente utilizado em escravos ou mesmo libertos.

Interessante a grafia grega Radius, sobretudo porque Caius não foi escrito com «G» (cf. n. $\left.{ }^{\circ} 1\right)$. O ordinator e/ou o liberto não demonstram, por isso, ter assimilado a cultura latina de maneira correcta e completa. E qual a razão da omissão dos «r» na penúltima linha ?... Erro do lapicida ? Aproveitamento do espaço ? Vestígios da oralização do latim? ... Pena é que não disponhamos de outros elementos de análise neste campo, uma vez que não pudemos aceder a uma fotografia do monumento.

O terminus post quem deste monumento poderá ser 45 a.C., uma vez que o lapicida demonstra conhecer as regras ditadas pela Lex Iulia Municipalis. A referência à tribo Galéria pode apontar para os tempos do imperador Augusto, estendendo-se a toda a dinastia dos Júlios-Cláudios. Tratando-se de uma inscrição funerária, a ausência de fórmulas corrobora numa datação de fins do séc. i a.C. ou inícios do séc. i d. C. No entanto, se pensarmos na forma como foi elaborado o texto - o dedicante dedicou-o também a si próprio, em vida -, a inexistência de fórmulas pode justificar-se no caso, bem provável, de se tratar de uma placa, destinada a ser colocada num grande monumento de família...

(47) KaJAnto, 1965, p. 65-6 e 248. 
0 papel dos Cadii na romanização está neste caso atestado de forma indubitável, seja em que zona tiver sido... Assim como o seu poder económico, patente no tipo monumental da homenagem fúnebre prestada, na cidadania alcançada.

GIL VI 1508

[G \{aio) . C(adi)?]0 . L (ucii) . F (ilio) . RVFO / PRO(co/istfZ $i)$ $[\ldots] / \operatorname{PATRONO}(\ldots)$

Bibliografia :

PIR, II, p. 1-2 ; R. E., III, 1, p. 1170.

A Caio Cádio Rufo, fillho de Lúcio, procónsul (do Ponto e da Bitínia), (...), patrono, (...).

Trata-se de uma inscrição honorífica, bilingue e fragmentada, dedicada por algumas civitates Ponti et Bithiniae a Caio Cádio Rufo, que aí foi proconsul entre 43 e 48 d.C., tendo sido destituído do cargo e condenado em 49 d. C., devido a um caso de leges repetundarum. Cunhou moeda com o seu nome em Niceia, Nicomédia e na Bitínia, de que era patrono. Sob Otão, em 69, foi perdoado e reingressou no Senado.

Seria este Caio Cádio Rufo o dono do escravo Cimbro do texto anterior? Quais as suas relações com os Cadii da Lusitânia, nomeadamente com os C. Cadii de Aeminium e o Cadius Rufus de Almourol? Teriam sido, ao menos, contemporâneos...

Apesar de ter sido identificada em Roma, esta inscrição diz respeito, mais propriamente, à parte oriental do Império, Ásia Menor, onde a língua vigente era o Grego. Por isso, o nome aparece sob a grafia Taiou KocSlou 'Poutpou, embora surja também em Latim: o lapicida dominava perfeitamente as duas línguas. 
E E Vili $124^{5}$

\section{$[\ldots] /$ C(aius) . CADIVI) . SEPTIM(^P) / [ ...]}

Bibliografia :

Notizie delle Scavi, 1887, p. 298; Forcellini, Y, p. 297.

O nome Caio Cádio Sétimo ( ?) figura, entre muitos, numa inscrição fragmentada de grandes dimensões proveniente de uma necrópole da cidade de Teate $\left({ }^{48}\right)$, antiga capital dos Marrucini $\left({ }^{49}\right)$, situada na costa do Adriático.

$\mathrm{O}$ alinhamento à direita foi conseguido de uma forma interessante, separando a última letra dos cognomina e situando-a na margem direita do campo epigráfico.

Tratar-se-á, portanto, de um epitáfio incluído num (ou ele próprio) monumento funerário de uma grande família, e enumerando todos os seus parentes, clientes e herdeiros. Não apresentamos aqui todo o texto na medida em que o não achamos necessário, mas são realmente mencionados trinta e dois nomes todos eles masculinos e todos utilizando tria nomina, sendo sempre o praenomen abreviado. Sendo assim, qual o estatuto social do nosso Caio Cádio Sétimo?...

O cognomen será aqui, preferencialmente, Septimus ou Septimianus, nomes que fazem parte, qualquer deles, do grupo de cognomes relativos às condições de nascimento: identificariam o sétimo filho do casal ou o sétimo a usar aquele nome. Septimius, derivado dos anteriores, é menos comum $\left(^{50}\right)$.

Parece tratar-se de cidadãos romanos, com posses. Pudemos verificar que muitos dos gentilicios associados a estes Cadii tiveram paralelos ilustres dentro das altas estirpes sociais, em Roma como na Hispania. São referidos dois Annaei, por exemplo - à gens Annaea pertenciam os doutos Annaeus Seneca, cavaleiros e tra-

(48) BÉSNIER, 1914, p. 466-7.

(49) BÉSNIER, p. 264.

(so) KaJAnto, 1965, p. 74,155, 293. 
dicionalmente professores em Córdoba; o filho Séneca foi professor de Nero, em Roma, e cônsul em 57 (51). À ordem senatorial pertenciam os Herrenii, segundo Schulze, uma gens nobilíssima e secular de origem osca ou etrusca (52).

Difícil é sugerir, ainda, alguma cronologia para este monumento, apenas com base nestes elementos... Mas a verdade é que, ao ser nele incluído, Caio Cádio Sétimo deixa transparecer algum do poder económico dos Cádios, mais uma vez.

\section{Os Cadii}

O comentário dos textos apresentados permitiu-nos situar sumariamente os Cádios num espaço e tempo definidos. Mas, afinal, será possível saber algo mais a seu respeito ? Disporemos de elementos susceptíveis de nos elucidar sobre a sua origem, o seu estatuto, a sua importância?

\subsection{Origem}

Schulze atribui aos Cadii uma origem etrusca: «Os Etruscos terão tido grande dificuldade em separar Catius, Cattius e Cadius» (53), apesar de Holder, com quem não concorda, considerar Cattius uma forma céltica. Por seu lado, M. L. Albertos ( ${ }^{54}$ ) apresenta um mapa de distribuição dos nomes «Cadus, Cadius y derivados», parecendo discordar de Schulze, que afirma a latinidade dos Cadi face aos Cadii de raiz etrusca cujo gentilicio teria sido formado a partir do sufixo -ius, diferente do sufixo - $u s$ de raiz latina. Esta autora aproxima, portanto, as duas formas que Schulze diferencia, pelo menos ao nível da antroponimia pré-romana da península, relativa à onomástica de base indo-europeia.

Nenhum dos dois linguistas se refere, no entanto, à forma Radius, também documentada na Hispânia, que é justificada, no

(51) Forcellini, V, p. 124.

(52) Ibidem, p. 728.

(53) SChulze, 1966, p. 76.

(54) Albertos, 1976, p. 77. 
Onomasticon de Forcellini, como sendo a grafia mais antiga da palavra (t. V, p. 297). A mesma fonte considera derivados de Cadius os gentilicios Cadienus (CIL XI 389) e Cadillo, (GIL II 971) na Península Ibérica, nada avançando quanto à sua evolução linguística e etimológica.

Ora, sabemos que as gentilidades etruscas teriam tido por base nomes próprios, por vezes derivados de substantivos comuns (ss). Avançando etimologicamente neste sentido teríamos, em latim cadium, ii e cadus, $i$, substantivos comuns para designar o mesmo objecto - um pequeno jarro, na última forma, destinado específicamente a conter vinho. Cadus é apresentado como derivando do grego xa\$oç, do hebraico $k a d(56)$. A forma cadium tem também em xaSiou, um paralelo grego de conotação semelhante $\left({ }^{57}\right)$.

Temos conhecimento dos intensos contactos culturais e comerciais existentes entre as cidades da Antiga Grécia e a nascente civilização etrusca $\left(^{58}\right)$. Sabemos ainda que, na Antiguidade, o principal objecto de comércio entre o Mediterrâneo e os povos celtas era o vinho, «arqueológicamente documentado nos vasos importados que se utilizavam para o beber e servir» (59). Uma das coisas que aparece com maior frequência nos túmulos etruscos são precisamente as cerâmicas gregas. Não nos é difícil, por isso, imaginar que essas palavras tenham entrado no vocabulário etrusco por esta via.

Da mesma forma, se pensarmos no papel assumido pela Etrúria na formação e desenvolvimento dos povos do Lácio e da futura urbs imperatoria, pelo menos até 509 a.C. $\left({ }^{60}\right)$, também não é difícil sugerir terem estas palavras persistido paralelamente no vocabulário latino devido à influência etrusca inicial...

Conhecemos a excessiva tendência de Schulze no que respeita à atribuição de raízes etruscas, mas os seus argumentos não parecem desprovidos de sentido: para Catius cita inscrições de Luca,

(55) SCHUlze, 1966, p. 65.

(56) OXford, 1968; Ernout, Meillet, 1959.

(57) OXFORD, 1968.

(58) Grimal etalii $t$ 1986, p. 91.

(59) Pigot, 1981, p. 245.

(60) Grimal et alii, 1986, p. 166. 
Sutrium e Careiae (CIL IX 1533, 3254 e 3764, respectivamente); para Cattius uma de Sutrium (CIL IX 3254), todas localizadas em cidades da Antiga Etrúria ou na Ümbria vizinha. Para Cadius cita as da Hispania por nós apresentadas (nomeadamente CIL II 6271). Parecendo ir de encontro ao raciocínio deste investigador, encontramos para Catius um outro paralelo na Insúbria, também vizinha da Etrúria: um Titus Catius que Cícero refere como epicurista (Fam. 15, 16) $\left({ }^{61}\right)$.

Em virtude desta distribuição, e alheando-nos por enquanto da hispânica, não seria difícil admitir a hipótese de, talvez até porque casualmente os sons gregos fossem homófonos com os etruscos, terem estes, uma vez «latinizados», adoptado na antroponimia paralelos greco-latinos que lhes eram familiares, à maneira dos indígenas que escolhiam cognomina latinos homófonos com o seu substracto linguístico... O referido Onomasticon considera, porém, uma filiação céltica do nome Catius, uma vez que é extremamente comum na Gália Cisalpina e Narbonense e muito raro noutros lados. Parece também concordar com Holder, na medida em que considera Cattius a grafia antiga de Catius $\left({ }^{62}\right)$.

Deste modo, os investigadores não estão de acordo quanto à filliação linguística dos antropónimos citados. Por nosso lado, o considerá-los célticos levaria a julgá-los hispânicos, como M. Lurdes Albertos, com quem não concordamos. Por isso, tentámos a via etrusca.

A origem dos Etruscos é ainda bastante obscura, mas parece ser mais ou menos aceite o facto de serem o fruto de uma síntese entre as tradições itálicas vilanovenses e grupos populacionais vindos da Ásia Menor, por volta do séc. ix a.C., para se estabelecer a norte do Tibre ( ${ }^{63}$ ). Sabemos ter existido, na Antiguidade, a cidade de Cadi na Ásia Menor ( ${ }^{64}$ )... Relacionada ou não com os Etruscos, o substracto linguístico será talvez o mesmo, uma vez que, embora não sem muitas dúvidas e interrogações, o etrusco parece poder ser

(61) R. E., vol. Ill 2, p. 1792-94.

(62) Forcellini, vol. V, p. 297.

(63) Grimal et alii, 1986, p. 158.

( ${ }^{\text {fl4 }}$ BÉSNIER, 1914, p. 154, na Frigia Epícteta. 
considerado um prolongamento mediterrânico das línguas da Ásia Menor 165), uma língua não indo-europeia, possivelmente...

Fosse qual fosse a sua origem, é certo terem existido Cádios na Lusitânia. Mas de onde teriam vindo ?

M. L. Albertos considera-os, juntamente com os Cadi como já vimos, indígenas, mas não explica porquê. As relações familiares de alguns Cádios com elementos femininos autóctones estão indubitavelmente documentadas, como também vimos. Contudo, os textos, para já não falar dos contextos, das inscrições referentes a Cadi são tão diferentes!... Citamos, como exemplo, ILER 5464 (= CIL II 6338), de Falência, em que o filho Amio e o seu amigo Algigo dedicam um epitáfio a Marco Cado Pedaquiano, de trinta anos. O substracto indígena encontra-se aqui bem patente, em todos os seus aspectos. Que contraste com a nossa inscrição n. ${ }^{\circ}$, a nível de texto, de antroponimia, de paginação e monumentalidade!... Ao contrário do que pensamos das outras, será, realmente, uma indígena Valéria Rufina?...

Todos os epitáfios, à excepção do n. ${ }^{\circ} 5$ talvez, revelam um índice cultural bastante elevado, um perfeito à-vontade no manejo da cultura e da língua latina falada e escrita, a que podem aludir os instrumenta scriptoria das paredes laterais dos monumentos (n. $\left.{ }^{\circ} 2\right)$. Porquê esta temática decorativa tão incomum na escultura funerária e tão típica dos monumentos funerários de Aeminium e Conimbriga? Reminiscências dos ideais orientais da 7uaißsia helénica?...

Temos de reconhecer que um nível cultural deste tipo seria normal, mesmo em indígenas, nos meados do séc. $\mathrm{n}$ ou inícios do séc. ui, isto é, após três séculos de romanização... O mesmo não seria tão comum nos meados do séc. i!...

De igual modo, a «grafia grega» documentada na identificação - Gaio Kádio por Caio Cádio - leva-nos a relacionar estes C. Cadii com os C. Cadii documentados em Roma, também nos meados do séc. i onde, na parte grega de uma inscrição bilingue, Caio aparece escrito com «G»)(T) e Cádio com«K»(K). Semelhança ao nível da grafia: semelhança ao nível da origem ?... Um elo de ligação entre estas semelhanças seria a inscrição $n .^{\circ} 5$, em que se verifica a utilização

(a6) Grimal et alii, 1986, p. 159. 
de uma grafia mista: Gaio Cádio por Gaio Gádio à latina, ou Gaio Kádio à grega, embora traduzindo mais a influência da linguagem oral, talvez, do que os efeitos de uma aculturação demasiadamente rápida.

Assim, discordamos da tese que explica a grafia «grega» pela antiguidade da forma Radius em relação a Cadius, quanto a nós preferencialmente atribuível a diferentes contextos culturais, fruto de influências orientais, bem ou mal assimiladas.

Qual a relação entre a nobre gens Cadia de Roma e a(s) rica(s) e culta(s) gens K/Cadia de Aeminium? Quais as suas relações com a parte oriental do Império ?

Discordamos assim de M. L. Albertos. Não nos parece viável a ideia de os Cadii hispânicos serem indígenas, ou mesmo «célticos», como pretende Holder. Seriam antes uma gens latina exógena (talvez da origem etrusca, segundo Schulze) qual teria vindo para a Hispânia no decorrer do período de organização do território, possivelmente ao tempo dos impérios de Cláudio e Nero, cronologia para que apontam todos os documentos hispânicos conhecidos.

\subsection{Estatuto}

Os testemunhos apresentados parecem referir-se claramente à existência de duas categorias de Cadii fora da Hispânia: os Cadii senadores em Roma, nos meados do séc. i e os $K /$ Cadii libertos do Sul da Península Itálica (Gampânia), talvez contemporâneos dos anteriores.

Tratando-se de uma cronologia tão alta, e sendo conhecido o hábito de associar um ou mais praenomina determinados ao gentilicio de família $\left({ }^{66}\right)$ - aquele(s) que depois se transmitia(m) ao primogénito varão, aos libertos, aos adoptivos, etc.- - não seria de todo improvável que o Caius Cadius procônsul do Ponto e da Bitínia fosse o próprio (ou um seu familiar directo) patrono do escravo Cimber, ... embora não o possamos afirmar.

Os Cádios da elite senatorial de Roma parecem ter tido a suficiente projecção sócio-económica para se manterem por mais de

(66) Cagnat, 1914, p. 68.

Conimbriga, 28 (1989), 169-203 
um ano no cargo de uma magistratura anual. Aliás, os governadores das províncias senatoriais da Ásia Menor eram, normalmente, senadores romanos no auge do seu cursus honorum, «pertencendo, portanto, ao círculo íntimo de pessoas e famílias que compartilhavam, sob a supervisão imperial, o governo dos destinos de Roma» $\left({ }^{67}\right)$. Os próprios libertos parecem orgulhar-se de os ter tido como patronos (cf. n. ${ }^{\circ}$ 5) ... Os K/Cádios libertos, por outro lado, dão a impressão de ter, de algum modo, partilhado o prestígio dos seus patronos «nobres».

E que pensar dos Cádios da nossa inscrição n. ${ }^{\circ} 7$ ? Aparecem, pelo menos, mencionados a par de gentilicios que primam pelo desafogo económico e o prestígio social dos seus portadores...

Trata-se, portanto, de elites externas. Qual a sua relação com os Cadii da Lusitânia?

Lembremo-nos de que todos os testemunhos epigráficos de Aeminium e o de Almourol foram paleograficamente localizados nos tempos de Cláudio e Nero, parecendo o texto perdido dos G. Kadii poder ser contemporâneo.

E recordemos, mais uma vez, a Caio Cádio Rufo, procônsul de 43 a 48 d.C., portanto, em pleno reinado de Cláudio. De acordo com o sistema estabelecido por Augusto, teria sido cuidadosamente escolhido para as funções de entre os senadores mais antigos ( $\left.{ }^{68}\right)$. $\mathrm{O}$ bom cumprimento dessas funções terá talvez justificado a prorrogação do seu mandato. $\mathrm{Na}$ verdade, a partir de Augusto, os governadores de província tenderam a ser mais conscienciosos, e teríamos tomado Cádio Rufo como exemplo se, em 48, não tivesse sido acusado de leges repetundarum pelos mesmos bitínios que antes o intitulavam patronus. Porquê?...

Sabemos que, durante o seu mandato, cunhou moedas gregas e bilingues anualmente $\left({ }^{69}\right)$ : a primeira comemorativa do nascimento de Britânico, ostenta a legenda latina Britannici Caesaris, algumas com Claudii ou Britannici, por fim, uma com Messalina, em Niceia, e uma última, em 48, com [MsJaaaXsiva ZeßaaT?)[vsa 'Hpa] em Nicomédia: o ano em que é condenado, o ano em que

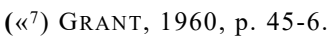

(68) Ibidem, p. 50.

(69) PIR II, p. 1-2. 
Messalina se divorcia de Nero, o mesmo ano em que este a manda matar $\left({ }^{70}\right) \ldots$ Traduzirão estas moedas alguma espécie de apoio ou contestação, por parte do procônsul, às ambições de Messalina?

Terá sido Caio Cádio Rufo justamente condenado? Ou teria sido apenas mais uma vítima das intrigas cortesãs, frequentes nos finais da dinastia júlio-claudiana?

Uma das particularidades do imperium de Cláudio foi a fundação de um gabinete secreto imperial de libertos. Estes, normalmente orientais e, em particular, da Ásia Menor, «de poder e riqueza sem precedentes, competiram ou cooperaram com a terceira e quarta esposas do imperador» $\left({ }^{71}\right)$.

Recordemos, então, o liberto de Caio, Caio Kádio Cimbro, o qual poderá ter sido coevo, como dissemos. Não poderia estar, eventualmente, a sua importância social — se pudermos ver no texto vestígios do orgulho que os dois filhos sentiam em ser filhos do liberto de C. Cádio... - relacionados com estes factos, com estas intrigas?... Um liberto ficava ligado ao seu patrono por laços de clientela, que o sujeitavam à prestação de serviços algo mal definidos, e à permanência na sua dependência económica, até certo ponto. Contudo ( $\left.{ }^{72}\right)$, estes condicionamentos não se estendem aos seus descendentes, e um filho de liberto será cidadão como qualquer outro, se for caso disso. A filosofia que presidiu à criação do gabinete secreto imperial de libertos ter-se-á, certamente, baseado nestes pressupostos.

Pensamos, assim, que, talvez para seguir as filosofias bucólicas difundidas no século de Augusto ( ${ }^{73}$ ), por necessidades de exílio e/ou por vergonha da virtus maculada, talvez até porque aqui tivessem uma villa de província $\left({ }^{74}\right)$, os Cádios vieram para a Lusitânia, estabelecendo-se no território da civitas Aeminiensis.

Qaul o seu valor aqui?

A nosso ver, ambas as categorias gentilicias por nós definidas se encontram aqui presentes, desempenhando, aparentemente, um importante papel no seio da burguesia municipal da cidade.

(70) Stevenson et olii, 1964, p. 555.

(71) Grant, 1960, p. 26-7 e 51.

(72) Grimal, 1986, p. 205.

(73) Pereira, 1982, p. 233 e 236.

(74) Grimal, 1985, p. 85-7. 
Primeiro os G. Kadii, libertos, ligados à também importante gens Albania, de libertos de Cádis. Documentados mesmo em Aeminium, aí estariam radicados.

Depois os L. Cadii de Montemor, provavelmente da villa da Senhora do Desterro. Consideramo-los de inequívoca filiação «nobre». A sua importância e o seu prestígio na cidade seriam grandes: ao ponto de uma mãe solteira, indígena, não baptizar o filho com o seu gentilicio (aliás importante a nível local $\left({ }^{75}\right)$ ), o que geralmente acontecia aos filhos naturais, mas com o próprio gentilicio do pai, que o terá certamente reconhecido... Este filho, educado na cultura clássica pelo elevado nível cultural que parece transparecer do seu monumento funerário, homenagem de sua mãe, terá certamente ( ?) desempenhado também algum papel de relevo na administração local.

Assim, de elites externas, os Cádios ter-se-ão convertido em elites internas, fomentando o desenvolvimento económico, político e cultural local.

Ainda um argumento a favor da importância dos Cadii, e com eles, provavelmente, da própria Aeminium: Caio Cádio Rufo, o procônsul, será perdoado por Otão em 69, e readmitido no Senado... Otão $\left({ }^{76}\right)$, amigo pessoal de Nero (e membro de uma ilustre família etrusca), foi afastado para o governo da Lusitânia quando o imperador manifestou desejos de desposar a que fora até então sua esposa, a bela Popeia. Ajudou Galba a destronar Nero e, depois, ele próprio destronou Galba.

Necessitou, portanto, de garantir o apoio senatorial a um imperium tão traiçoeiramente conseguido. Terá sido, talvez, também essa a razão do perdão para os Cadii, concedido ainda antes de ser morto pelas tropas de Vitélio. Condição requerida pela «burguesia» da civitas eminiense em troca do seu apoio a Otão e, eventualmente, ao próprio Galba?... Ou será tudo apenas uma grande coincidência?...

Qual o papel dos Cádios de Almourol ? Qual a sua relação com Aeminium? ... Apesar da cronologia sugerida por Borges de

(75) Étienne, Alarcão, 1976, p. 98.

(76) Stevenson, 1964, p. 590-1. 
Figueiredo, pensamos serem contemporâneos dos eminienses, anteriores ao ano dos quatro imperadores. Que pensar da sua filiação externa e interna?

Documentada está a ligação matrimonial com indígenas, o que não seria, talvez, tão próprio da elite senatorial, embora se saiba que as leis do coração não são deste mundo... A corroborar a sua filiação na categoria dos libertos estará, porventura, o carinho e o sentimento depostos na redacção do formulário, em que os filhos são tratados pelos cognomina e é acentuada a saudade pela esposa. $\mathrm{O}$ orgulho com que é mencionado o facto de ter um dos filhos em Roma, seria também, eventualmente, típico daquela burguesia local de origem servil ou indígena, que, tendo enriquecido, ou tendo posses para isso, manda os seus filhos estudar em Roma, ou na capital da província (77). Embora sendo uma placa, destinada, portanto, a ser aplicada num monumento de maiores proporções, nada tem já da graciosidade clássica dos monumentos eminienses, à parte a elegância das pequenas folhas de hera na invocação inicial... semelhantes às utilizadas no epitáfio dos L. Cadii de Montemor, aliás... O facto de viverem numa villa, de terem um jazigo de família, acentua, apesar disso, a ideia do seu poder económico e consequente prestígio social.

Deste modo, três coisas, pelo menos, caracterizam todos os Gádios: o seu desafogo económico; o seu prestígio social; a sua largueza intelectual. Algumas dúvidas subsistem, no entanto: por que razão o padrão de identificação recomendado pela lex Iulia nunca foi utilizado nos formulários encomendados na Hispânia?... A filiação é sempre indicada, de maneira indirecta, na expressão dos laços familiares, mas a tribo nunca foi mencionada... Sinal de cidadania incompleta, ou da damnation...

\subsection{Importância}

Beneficiando da imperial pax romana, as duas civitates do Mondego terão gozado, como as províncias romanas no geral, de um período de franca dinamização económica e social, trabalhando as

(77) GRIMAL, 1985, p. 76-7. 
burguesias municipais no sentido da promoção jurídica a um estatuto mais vantajoso - não esqueçamos que, a acreditar em Plínio, Aeminium e Conimbriga estariam sujeitas ao pagamento de um stipendium desde o tempo de Augusto.

$\mathrm{O}$ facto de não haver Cadii epigraficamente atestados em Conimbriga, poderia restringir, à partida, a sua acção ao território da civitas eminiense. Contudo, convém não esquecer que não se conhece ainda a necrópole de Conimbriga...

De qualquer modo, os Cádios não terão tido dificuldade em chegar a Aeminium, ponto de passagem obrigatório da via Olisipo-Bracara.

Qual o valor da cidade na altura ? Os parcos vestígios arqueológicos referidos são dificilmente datáveis, mesmo a um nível estritamente hipotético, o que contibui para a manutenção das interrogações colocadas. No entanto, seguindo o raciocínio de Fabre e Le Roux (1971, p. 121), dada a precocidade do fenómeno da romanização a nível local, o processo de evolução político-económico devia estar bastante avançado e activo. É nossa opinião que os Cádios nele devem ter influído de forma directa e decisiva.

Como em todos os tempos, o poder económico, sobretudo se associado a um bom nível cultural, gera e alimenta o prestígio social, podendo facilmente transformar-se em prestígio político. Tudo se compõe para alicerçar a hipótese de um forte peso dos Cádios na administração local.

Economicamente, os seus contributos não terão sido escassos. Segundo o costume das elites romanas citadinas, os L. Cadii não terão vivido na cidade, mas sim numa villa suburbana próxima, pequena unidade de exploração agro-pecuária, certamente. A nobre actividade agrícola era cara às classes senatoriais abastadas e a distância à cidade, ou mesmo a Mérida, não seria muito difícil de percorrer. Lembremo-nos de que Galba soube da morte de Nero logo trinta e seis horas após a sua ocorrência, na distante capital da Tarraconense $\left({ }^{78}\right)$. Em todo o caso, o cognome Celia pode indicar a actividade agrícola significando celeiro, adega ou armazém em geral $\left({ }^{79}\right)$. A proximidade do rio tornaria bastante férteis as terras

$\left({ }^{78}\right)$ GRANT, 1960 , p. 45.

(79) OXFORD, 1968, p. 122. 
ribeirinhas da Senhora do Desterro. Contudo, essa mesma proximidade pode sugerir a existência de um outro sector económico, já com largas tradições no território: o comércio. Não seria essa a ocupação dos libertos G. Ràdio ...nilano e G. Kádio Salviano ? As influências gregas patentes na grafia dos seus nomes poderiam até explicar-se pelo facto de estarem habituados ao manuseamento frequente de moeda oriental - Cádis era conhecido como um dos portos peninsulares com mais contactos com o Oriente; recordemos as moedas cunhadas pelo nosso procônsul na Bitínia, ostentando sempre o seu nome em grego: Tatou KaStou Poucpou Av0o7ua0o $<7$ ria0povoa... A própria ligação com os Albanii de Cádis, família de libertos, normalmente dedicados ao comércio na cidade «com mais capitalistas do que qualquer outra do Império» $\left({ }^{80}\right)$.

Não esquecer ainda a importância das relações atestadas com a capital da Lusitânia $\left({ }^{81}\right)$ de ordem política, decerto, mas também, necessariamente, de ordem comercial, uma vez que, a norte do Tejo, Emerita parece ter funcionado como o principal centro abastecedor da Lusitânia ${ }^{82}$.

O carácter costeiro da cidade, a sua fácil acessibilidade, terão sido assim talvez determinantes para a fixação, temporária ou não, dos Cadii no local.

Embora situados numa região de francas possibilidades agrícolas, inclinamo-nos a atribuir o mesmo tipo de ocupação aos Gádios de Almourol, como vimos residindo também numa villa, eventualmente. Perto da confluência do Zêzere com o Tagus, portanto, nas margens de um rio de ampla navegabilidade ( ${ }^{83}$ ), que melhor situação para a actividade comercial ?

Os mosaicos «das suas villae» (possivelmente), a grandiosidade e qualidade dos monumentos colocados aos seus mortos - placas (a inserir num monumento de maiores proporções), pedestais, cipos ( ?), em mármore ou calcário de boa qualidade, decorados são os primeiros indícios, e os mais directos, do seu poder económico.

(80) Grant, 1960, p. 51.

(81) ENCARNaÇão, 1979, p. 172-8.

(82j Alarcão, 1988, p. 87.

(83) Centeno, 1981, p. 168, cit. Estrabão, III, 3,1. 
A nível cultural, a sua importância não terá sido menor. A correcção dos seus epitáfios — e lembremos o «avant-garde» das fórmulas utilizadas, o próprio padrão textual tão invulgar na Hispânia em monumentos de cronologias tão altas $\left({ }^{84}\right)$ - o classicismo atestado nas suas decorações (n. ${ }^{\circ} 3$ e 4, nomeadamente), o facto de os pensarmos oriundos do Oriente - portanto, dominando tão bem o Grego como o Latim - confere-lhes um incontestável grau de cultura. O seu papel no domínio da romanização local terá sido, assim, forçosamente importante, sobretudo porque conhecemos a sua fusão, directa ou indirecta, com elementos da população indígena - Alleicela Avita e Cornelia Albura.

Embora não tenham sido, certamente, os únicos agentes da romanização local, o facto de uma elite senatorial externa se ter, de forma mais ou menos permanente, estabelecido no território, terá determinado, ou até exigido, uma adequação cultural mais rápida dos seus habitantes indígenas que, aliás, revelavam, de antemão, uma grande facilidade de aculturação.

Estes contributos têm também a sua importância a nível social: no âmbito de um processo de romanização rápida e precoce, temos documentada a união do substracto indo-europeu pré-existente com um substracto exógeno latino, e, mais do que isso, de elites externas com as elites internas locais : o exemplo de Cádio Cariano e, talvez também, o exemplo dos Cádios de Almourol.

Deste modo, ligados ao comércio e/ou à agricultura (e indústria?), os Cádios tornaram-se parte integrante da burguesia administrativa local, acompanhando o processo evolutivo do crescimento da Aeminium romana, desde os Júlios-Cláudios até... quem o sabe ? ...Não poderiam, uma vez perdoados, ter intercedido junto das entidades imperiais e provinciais no sentido da municipalização de Aeminium ?

Em conclusão: conhecemos os Cadii como uma família nobre, com assento no Senado, e cujos elementos seguiam normalmente o

(84) Alarcão, Étienne et olii, 1976, p. 209. 
EST. I

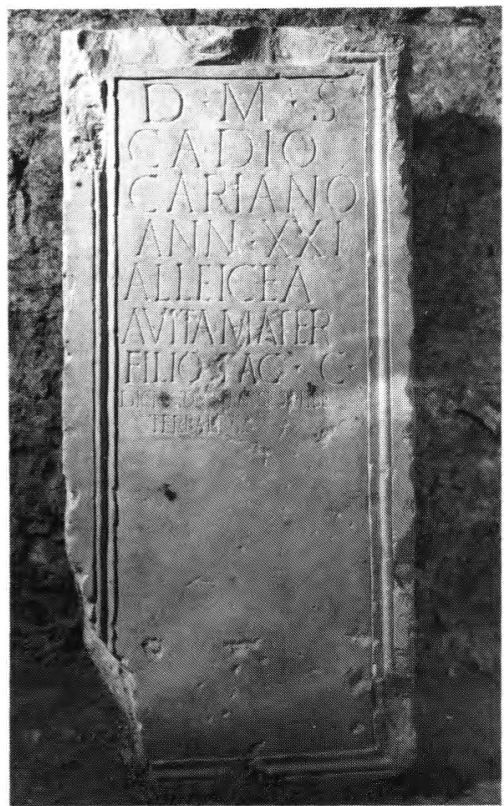

O monumento de Aeminium

(Fot. do Museu Nacional de Machado de Castro) 
EsT. II

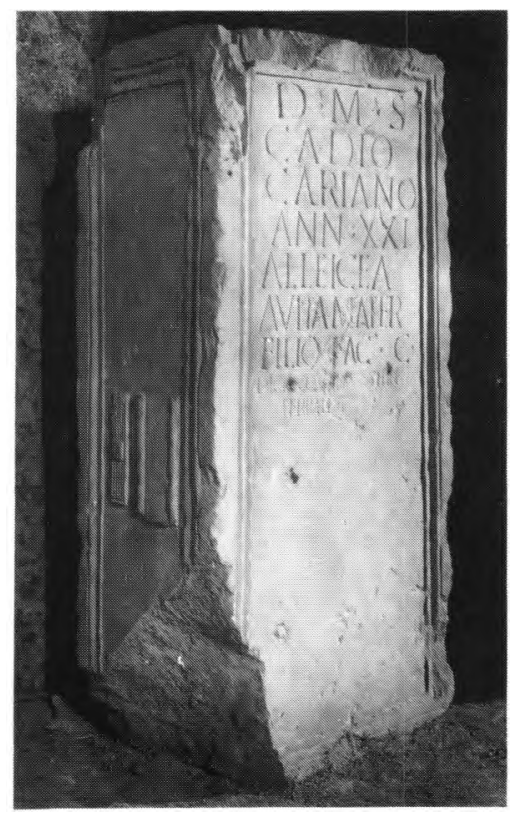

O monumento de Aeminium

(Fot. do Museu Nacional de Machado de Castro) 
EsT. Ill

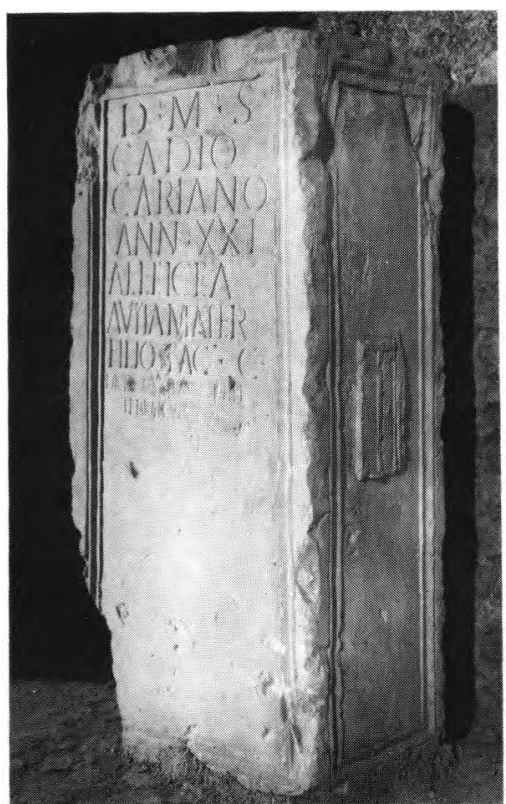

O monumento de Aeminium

(Fot. do Museu Nacional de Machado de Castro) 
EST. IV

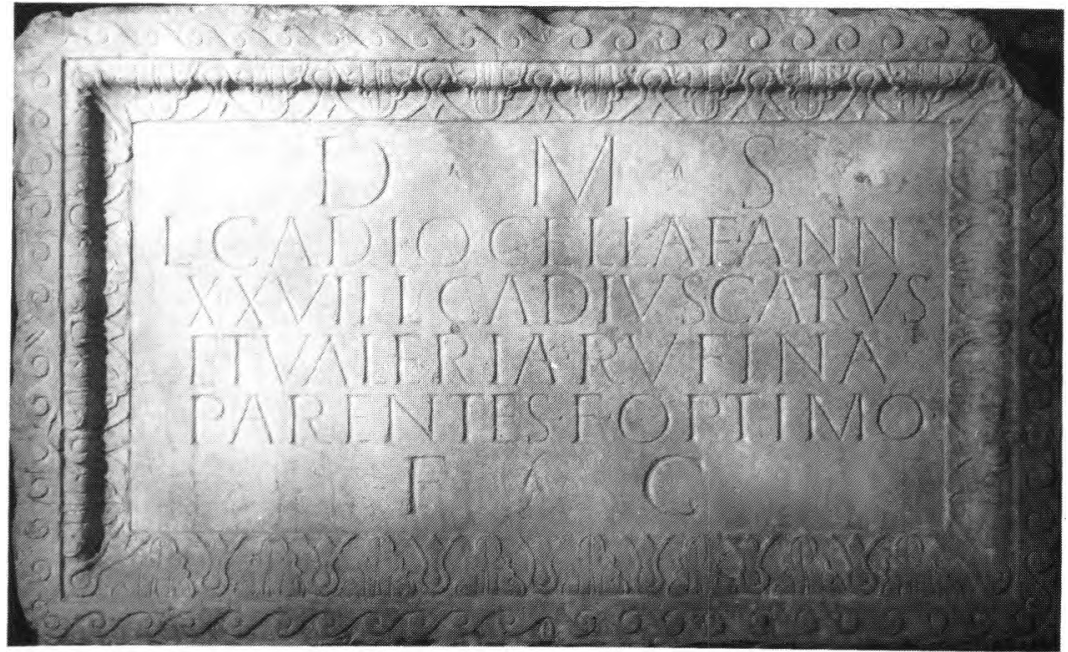

A placa de Montemor-o-Velho (Fot. do Museu Nacional de Machado de Castro) 
EsT. V

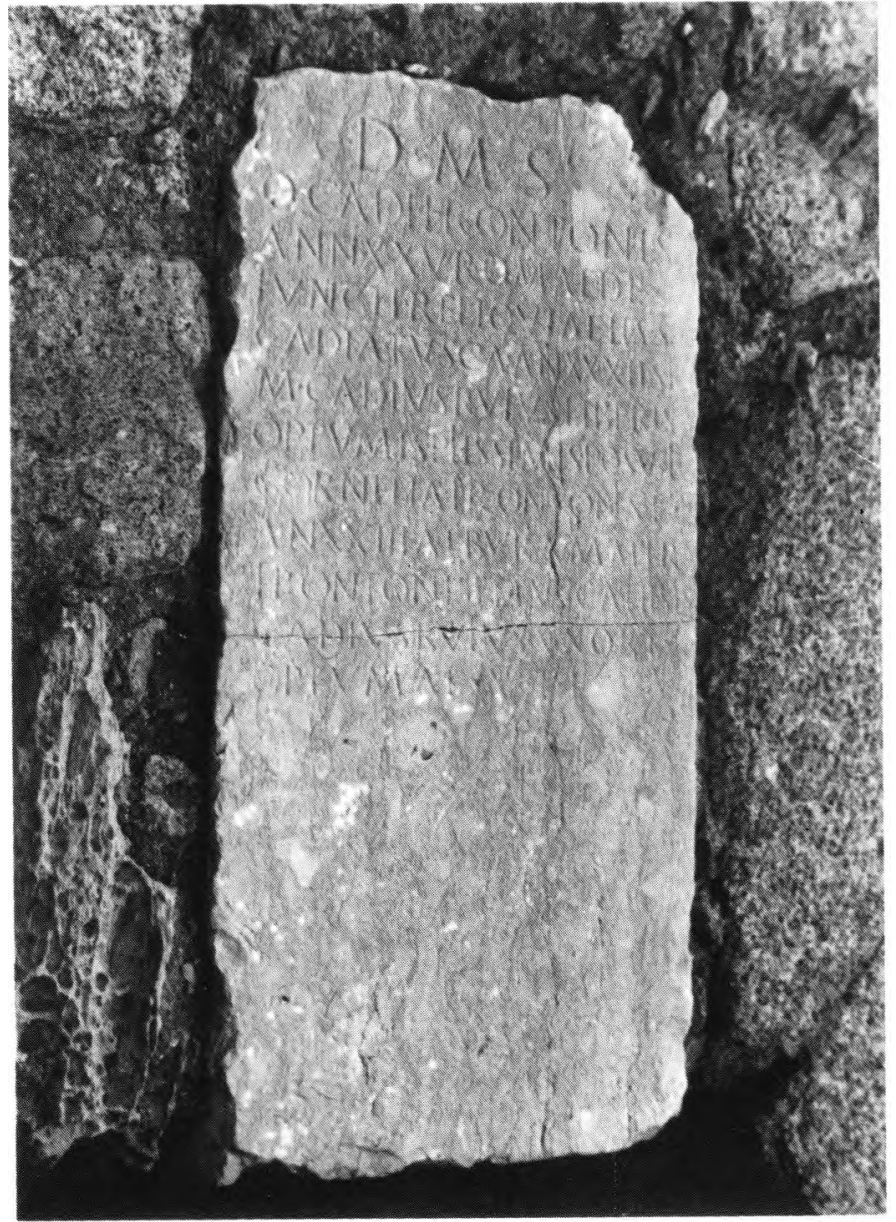

A placa de Almourol (Fot. de J. M. Bairrão Oleiro) 
(Página deixada propositadamente em branco) 
caminho do cursus honorum. Devia ser uma família influente e importante porque um procônsul Cadius, magistratura normalmente de eleição anual, ocupou o cargo durante quatro anos, até ter caído em desgraça. A sua eventual raiz etrusca poderia ter sido até um factor do prestígio sócio-político que os caracterizou, pelo menos até aos meados ou finais do séc. i d.C.. Depois, algures entre o último quartel do séc. i a.C. e os meados do séc. i d.C. a libertação de um escravo terá dado origem a um novo ramo da gens: uma gens Cadia de libertos, também estes importantes, ao ponto de cedo ter adquirido a cidadania romana (talvez no Oriente, devido à grafia grega que utilizam na sua identificação...).

Contemporâneos dos primeiros, e talvez também dos segundos citados, são os Cádios de Aeminium. Pensamos ter documentado as relações entre eles e as duas categorias de Cadii exógenas antes apresentadas: os de filiação claramente «nobre» da villa da Senhora do Desterro; os de filiação claramente liberta de Aeminium, (ligados, aliás, a uma importante gens de libertos de Cádis). Estes últimos também se identificam à grega. Essas influências orientais, parecendo não perdurar a nível de antroponimia, talvez se possam considerar ligadas à temática «culturalista» dos monumentos epigráficos eminienses.

Matrimonial ou extra-matrimonialmente, os Cadii não parecem hesitar em ligar-se com elementos da população indígena local, e também o seu papel de agentes da romanização pôde ser aqui realçado. A sua envolvência, directa ou indirecta, na dinâmica política, social, económica e até cultural da civitas eminiense parece-nos comprovada, e ambas as categorias de Cadii identificadas se poderão considerar membros influentes da burguesia municipal da cidade.

Terão permanecido, com estas características, na Lusitânia, sempre perto das vias de comunicação fluviais e terrestres... A sua presença aí após o ano dos quatro imperadores é incerta... Não conhecemos qualquer outro documento epigráfico que os refira, pelo menos.

Ter-se-ão afastado de Aeminium?... Ter-se-ão ido embora após o perdão de Otão?...

Para obter mais respostas, e para ter algumas certezas, seris necessário termos tido possibilidade de acesso a muitos main 
corpora, espalhados por todo o Império, e, inclusivamente, de analisar as próprias pedras, numa tentativa de as datar, de conhecer melhor os seus contextos arqueológicos, se possível. Entretanto, ficam de pé as hipóteses, levantados na sequência de todo um incrível conjunto de coincidências, as quais parecem poder relacionar entre si sete inscrições dispersas pelo território do Alto Império Romano...

\section{BIBLIOGRAFIA}

Ala RC Ão, J. de, Portugal Romano, Lisboa, 1983, 3. a ed. (= Alarcão, 1983).

----- Roman Portugal, Warminster, 1988 (= Alarcão, 1988).

---- , O Domínio Romano em Portugal, Mem Martins, 1988, (= Alarcão ${ }^{1}$,1988).

Alarcão, J. de; Étienne, R. (dir.), Fouilles de Conimbriga, II - Epigraphie et Sculpture, Paris, 1976 (= Étienne, Alarcão, 1979).

Albertos, M. de Lourdes, La Antroponimia Prerromana en la Península Ibérica, sep. «Actas del I Coloquio sobre Lenguas y Culturas Prerromanas en la Península Ibérica (1974)», Salamanca, 1976 (=Albertos, 1976).

--_-, La Onomastica Personal Primitiva de Hispania Tarraconense y Retica,

Salamanca, 1966(= Albertos, 1966).

Bailly, Dictionnaire Grec-F rançais, Paris, 1941 ( = Bailly, 1941).

Barra clough, G. (dir.), Le Petit Atlas de l'Histoire Mondiale, Paris, 1984.

B É SNIE R, M., Lexique de Géographie Ancienne, Paris, 1914 (= Bésnier, 1914).

Cagna T, R., Cours d'Épigraphie, Paris, 1914, 4. ${ }^{a}$ ed. (= Cagnat, 1914).

Centeno, Rui, A Dominação Romana, in «História de Portugal», vol. I, (dir. J. Hermano Saraiva), Lisboa, 1983 (=Centeno, 1983).

Chaves, L., Mosaicos Romanos em Portugal, «Revista de Archeologia», 3, 1936 (= Chaves, 1936).

Corre ia, Virgílio, Obras, I, Coimbra, 1946 ( - Correia, 1946).

Cruz, Belchior da, Notícias Várias, «O Archeologo Português», 4,1898 (= Cruz, 1898).

Descham Ps, Pierre, Dictionnaire de Géographie Ancienne et Moderne, Hildeshim, 1965 (= Deschamps, 1965).

EnCARnaÇão, J. d', Sociedade Romana e Epigrafia, Setúbal, 1979.

---- , Introdução ao Estudo da Epigrafia Latina, Coimbra, 1979.

----, Notas sobre a Epigrafia Romana de Coimbra, «Actas das I Jornadas do G.A.A.C.», Coimbra, 1979 (= Encarnação, 1979).

----- , Divindades Indígenas sob o Domínio Romano em Portugal, Lisboa, 1975 (= Encarnação, 1975).

Ernout; Meillet, Dictionnaire Etimologique de la Langue Latine, Paris, 1959, 4. ${ }^{\mathrm{a}}$ ed. (= Ernout; Meillet, 1959).

Figueiredo, Borges de, Miscellanea, «Revista Archeologica e Historica», II, 1888 (= Borges de Figueiredo, 1888). 
--_-, Miscellanea Epigraphica, opus cit., III, 1889 ( = Borges de Figueiredo, 1889).

Forcellini, Lexicon Totius Latinitatis, Onomasticon, V e VI ( = Forcellini).

Godwin, Greek Grammar, London, 1983 ( = Godwin, 1983).

Grant, M., O Mundo de Roma, Lisboa, 1967 ( = Grant, 1967).

Grimal et alii, Historia Geral da Europa - I. A Europa das Origens ao Começo do séc. XVI, Lisboa, 1986 ( = Grimal et olii, 1986).

Grimal, P., A Vida em Roma na Antiguidade, Lisboa, 1985 (= Grimal, 1985).

-.-., A Civilização Romana, Lisboa, 1988 (= Grimal, 1988).

H Ü BNE R, Corpus Inscriptionum Latinarum, II, Berlin, 1869 (e Suplementum, 1892) (= GIL II).

-_-_, Ephemeris Epigraphica, Vili, Berlin, 1899 (= EE).

Ka Jant o, Iiro, The Latin Cognomina, Helsinkki, 1965 (= Kajanto, 1965).

Le Roux, P.; Fa B Re, G., Inscriptions Latines du Musée de Coimbra, «Conimbriga», IX, 1971, (= Le Roux; Fabre, 1971).

Oxford Latin Dictionary, Oxford, 1968. (= Oxford, 1968).

Pauly s Realenciclopädie der Classischen Altertums-Wissenschaft, Stutgart, (vários volumes) (=RE).

Pere ir a, M. Helena da Rocha, Estudos de História da Cultura Clássica, II - Cultura Romana, Lisboa, 1984 ( = Pereira, 1984).

Pigot t, Stuart, A Europa Antiga, Lisboa, 1981. ( = Pigot, 1981).

Prosopographia Imperii Romani, II, Berlin/Leipzig, 1936 (= PIR).

Re Sende, Maria Ángela, Subsídios para o Estudo da Epigrafia Pagã em Portugal, Coimbra, 1971 ( = M. Angela Resende, 1971), policopiado.

Roch A, Santos, A Necrópole Luso-Romana da Senhora do Desterro, Montemor-o-Velho, «Portugália», 1, Porto, 1859-1903 ( = Rocha, 1903).

-_-_, Memórias e Explorações Arqueológicas, II, Coimbra, 1971 ( = Rocha, 1971).

Rodrigues, M. de Lurdes, Inscrições Romanas do Museu Machado de Castro, «Humanitas», VIII-IX, 1959-60 (= M. L. Rodrigues, 1959-60).

S A A, Mário, As Grandes Vias da Lusitânia, Lisboa, 1956 (= Saa, 1956).

Schulze, Wilhem, Zur Geschichte Lateinischer Eigennamen, Bulin, 1966 ( = Schulze, 1966).

Simões, Filipe, Escritos Diversos, Coimbra, 1888 ( = Simões, 1888).

S TE VENSON et olii, A Dictionary of Roman Coins, Republican and Imperial, London, 1964 ( = Stevenson et alii, 1964).

Su Sini, Giancarlo, Epigrafia Romana, Roma, 1982.

The Oxford Classical Dictionary, Oxford, 1970, 2. ${ }^{\mathrm{a}} \mathrm{ed}$.

Tor rinha, F., Dicionário Latino-Português, Porto, 1981.

Unte r mann, Elementos de un Atlas Antroponimico de la Hispania Antigua, Madrid, 1965 (= Untermann, 1965).

Vasconcelos, Leite de, Inscrição Romana de Montemor-o-Velho, «O Archeologo Português», XVIII, 1913 (— L. de Vasconcelos, 1913).

Vives, Inscripciones Latinas de la España Romana, Barcelona, 1971 (e indices, 1972)(= ILER). 